\title{
Dicationic triazolium fungicidal ionic liquids with herbicidal properties
}

\author{
Kamil Czerniak ${ }^{1}$ (1) $\cdot$ Romuald Gwiazdowski ${ }^{2} \cdot$ Katarzyna Marcinkowska $^{2} \cdot$ Juliusz Pernak $^{1}$
}

Received: 18 March 2019 / Accepted: 9 July 2019 / Published online: 16 July 2019

(c) The Author(s) 2019

\begin{abstract}
The purpose of the present study was to synthesize the dicationic ionic liquids exhibiting herbicidal and fungicidal activities. A homologue series of ten dicationic ionic liquids was synthesized using commercial triazole fungicide (tebuconazole) and evaluated in terms of their possible antifungal and herbicidal activities. Dicationic triazolium compounds containing different linkers were prepared via acid-base reaction between the corresponding dicationic hydroxides and herbicides in the form of free acids. Additionally, the ionic liquids were fully characterized using NMR and thermal analysis. The herbicidal efficacy was tested during greenhouse experiments, using lambsquarters and oilseed rape as the test plants. In the case of determination of antifungal activity, six fungal species were used: Sclerotinia sclerotiorum, Botrytis cinerea, Fusarium culmorum, Fusarium oxysporum, Colletotrichum sp. and Monographella nivalis. The obtained results indicate that the conversion of compounds into dicationic ionic liquids affects their fungicidal and herbicidal activity. In the case of tests carried out on fungi, no difference in activity was observed at higher doses, except Monographella nivalis. However, at lower concentration $(10 \mathrm{ppm})$, there is a reduction in efficacy compared to the reference substance. In addition, all obtained compounds are characterized by high activity.
\end{abstract}

Keywords Herbicide $\cdot$ Fungicide $\cdot$ Dicationic ionic liquid $\cdot$ Herbicidal ionic liquid

\section{Introduction}

Ionic liquids (ILs) are a vast group of chemical compounds characterized by a melting point below $100{ }^{\circ} \mathrm{C}$. The notable trait of ionic liquids is their ionic structure and the fact that they are considered as "designer" compounds. The selection of ions allows to control the physical, chemical and biological properties. One of the main classifications of ILs includes their three generations (Hough et al. 2007). The 1st generation comprises ionic ILs which exhibit unique physical properties. ILs characterized by additionally determined chemical properties are described as the second generation, whereas the third generation is characterized by targeted

Electronic supplementary material The online version of this article (https://doi.org/10.1007/s11696-019-00875-x) contains supplementary material, which is available to authorized users.

Kamil Czerniak

kamil.z.czerniak@doctorate.put.poznan.pl

1 Department of Chemical Technology, Poznan University of Technology, Poznan, Poland

2 Institute of Plant Protection, National Research Institute, Poznan, Poland biological properties. The last generation is of high significance due to the potential application of commercial and broadly used organic compounds (such as pharmaceuticals or pesticides), which are well studied in terms of properties, including their toxicity towards warm-blooded organisms and the natural environment (Bica and Rogers 2010; Shamshina et al. 2015).

The detailed review of pesticides, especially in EU, prevents and restricts the use of numerous efficient active compounds which have been employed for years. The design of ILs which comprise the commonly used compounds in the form of a cation or anion may be a cheap and efficient method. This allows to obtain new compounds as ILs with altered properties and retained efficiency of action of the substrate.

Herbicidal ionic liquids (HILs) are currently an alternative to commonly available pesticides and are defined as ILs containing at least one herbicidal ion (Pernak et al. 2011). They are safe due to their limited volatility in relation to, e.g., formulations containing an ester of a herbicidal acid (Cojocaru et al. 2013). In addition, they are characterized by the ease to regulate the toxicity of the preparation and allow to obtain preferred physiochemical properties by 
selection of appropriate counter-ion (Kordala-Markiewicz et al. 2014; Niemczak et al. 2019). The discovery of HILs in 2011 showed that it was possible to obtain a new type of more biologically active and potent herbicides based on different organic acids (Pernak et al. 2014a, b; Niemczak et al. 2017; Tang et al. 2018; Wang et al. 2019; Ding et al. 2014; Zhu et al. 2015). However, it is also possible to prepare salts which consist of a cation manifesting herbicidal activity (Piotrowska et al. 2016).

Novel types of dual functional salts include ILs which exhibit biological activity. Introduction of another functional counterion allows to obtain salts with additional properties (Lewandowski et al. 2014). It is possible to synthesize HILs with a cation used as a plant growth regulator or fungicide and an anion manifesting high herbicidal activity (Pernak et al. 2013, 2014a, b). In addition, bifunctional ILs derived from the plant resistance inducer BTH can be applied as a new type of a pesticide with antibacterial properties (Śmiglak et al. 2014, 2016).

Dicationic ionic liquids (DILs) comprise two identical or different monocations linked together by a rigid or flexible organic spacer and paired with two singly charged anions (Bhatt et al. 2015; Moumene et al. 2015; Al-Mohammed et al. 2015; Niu et al. 2018). Recently, DILs comprising imidazolium, ammonium, pyridinium, and phosphonium cations or their combinations to form asymmetric salts have been developed and extensively studied (Sahu et al. 2014; Yonekura and Grinstaff 2014). Important advantages of DILs in comparison to monocationic ILs include high thermal and chemical stability, larger liquid ranges, higher solubility of compounds, surface properties, and lower volatility (Chinnappan et al. 2015; Fareghi-Alamdari et al. 2016; Serva et al. 2016).

Triazoles are compounds consisting of a five-membered ring with three nitrogen atoms located at the 1,2, 3 or 1,2, 4 positions (Mehrkesh and Karunanithi 2013). Compounds containing the triazole group have found application as drugs which exhibit various biological activities, such as antibacterial, anti-tubercular, anti-HIV or alpha-lycosidase inhibition (Dai et al. 2015). Moreover, triazoles are widely used as pesticides for control of fungi which cause crop diseases (Cano and Santiago 2014). Application of the chemical protection in the form of fungicides has improved the modern agriculture by the increase of quality and yields of produced crops (Lucas et al. 2015).

Commercial triazole fungicides are represented by a diverse group of compounds applied for vegetable and fruit protection or material preservation (e.g., wood) (Han et al. 2014; Stamatis et al. 2015). Tebuconazole belongs to the triazole group of biocides and is used for the control of mildew, rust, net blotch, root rot, and seed-borne diseases. The most commonly available formulations are emulsifiable concentrates and wettable powders due to the low solubility in water (Šiviková et al. 2013; Zhang et al. 2015). Tebuconazole exhibits moderate toxicity to freshwater fish and a half-life in soil equal to 49-610 days under aerobic conditions (Bernabò et al. 2016; MuñozLeoz et al. 2011) The main action mode is the inhibition of the $14 \alpha$-demethylase in ergosterol biosynthesis, an important component in fungal cell membranes, by influencing the cytochrome P450 enzyme activity (Ngo et al. 2016; Bordagaray et al. 2013). Recently, ILs which are based on 1,2,3- and 1,2,4-triazolium heterocycles have found interest as materials for energy-rich applications such as explosives and propellant fuels, solvents, catalysts, efficient $\mathrm{CO}_{2}$ absorbents or antibacterial and chiral compounds (Brauer et al. 2015; Nagarajan and Kandasamy 2014; Reeder et al. 2016; Singh and Gardas 2016). Additionally, it is possible to synthesize protic and aprotic triazolium ILs with fungicidal properties (Pernak et al. 2015; ZabielskaMatejuk et al. 2015) or polymeric ILs (Zhang and Yuan 2016). The main purpose of this work was to prepare novel DILs exhibiting strong herbicidal and fungicidal properties. Studies were conducted due to the fact that currently there is a small amount of information on DILs based on tebuconazole and herbicidal acids in the literature. The synthesis of new dicationic liquids is important because it allows to obtain one compound indicating more than one biological activity that can be used as a versatile preparation with comprehensive efficacy.

\section{Experimental}

\section{Materials}

1,4-Dibromobutane (99\%, CAS 110-52-1), 1,6-dibromohexane (96\%, CAS 629-03-8), 1,8-dibromooctane (98\%, CAS 4549-32-0), 1,10-dibromodecane (97\%, CAS 4101-682), 1,12-dibromododecane (98\%, CAS 3344-70-5) were obtained from Sigma-Aldrich and used without further purification. Tebuconazole (98\%, CAS 107534-96-3) was purchased from Pestinova. Other chemicals and all solvents were obtained from Avantor Performance Materials Poland S.A. and used as received.

\section{General}

NMR spectra $\left({ }^{1} \mathrm{H}\right.$ and $\left.{ }^{13} \mathrm{C}\right)$ were prepared in deuterated dimethylsulfoxide containing TMS as the internal standard. Measurements were carried out using Varian Mercury 300 or Varian VNMR-S $400 \mathrm{MHz}$ spectrometers. Elemental analyses were performed at the Adam Mickiewicz University, Poznan (Poland). 


\section{Thermal analysis}

Thermogravimetric analysis was performed using a Mettler Toledo Stare TGA/DSC1 unit. Samples between 2 and $10 \mathrm{mg}$ were placed in aluminium pans and heated from 30 to $450{ }^{\circ} \mathrm{C}$ at a heating rate of $10{ }^{\circ} \mathrm{C} \mathrm{min}-1$ under the flow of nitrogen.

Thermal transition temperatures of the prepared salts were determined using a Mettler Toledo Stare DSC1 apparatus under nitrogen. Samples between 5 and $15 \mathrm{mg}$ were placed in aluminum pans and heated from 25 to $120^{\circ} \mathrm{C}$ at a heating rate of $10^{\circ} \mathrm{C} \mathrm{min}{ }^{-1}$ and cooled with an intracooler at a cooling rate of $10{ }^{\circ} \mathrm{C} \mathrm{min}^{-1}$ to $-100{ }^{\circ} \mathrm{C}$ and then heated again to $120^{\circ} \mathrm{C}$.

\section{Synthesis of triazolium dibromides}

A mixture of appropriate dibromoalkane $(0.05 \mathrm{~mol})$ and $50 \mathrm{~mL}$ of acetonitrile was placed in a semi-automated system EasyMax 102 (Mettler Toledo) equipped with a $100 \mathrm{~mL}$ glass reactor, magnetic stirring bar and reflux condenser. Next, tebuconazole $(0.1 \mathrm{~mol})$ was added and the reaction was carried at $80^{\circ} \mathrm{C}$ for $72 \mathrm{~h}$. After that time, the homogeneous mixture was cooled to $25^{\circ} \mathrm{C}$ and acetonitrile was removed by rotary evaporator (Büchi). Next, the obtained dibromides salts were purified by washing three times with hot hexane $(50 \mathrm{~mL})$ and dried under reduced pressure at $60{ }^{\circ} \mathrm{C}$ for $24 \mathrm{~h}$.

\section{Synthesis of DILs}

Appropriate triazolium dibromide $(0.01 \mathrm{~mol})$ was dissolved with $20 \mathrm{~mL}$ of methanol in $50 \mathrm{~mL}$ glass reaction EasyMax 102 (Mettler Toledo) equipped with magnetic stirring bar. Next, potassium hydroxide $(0.02 \mathrm{~mol})$ in the form of a methanolic solution $(10 \mathrm{~mL})$ was added and the mixture was stirred for $1 \mathrm{~h}$ at $25^{\circ} \mathrm{C}$. After the anion exchange reaction, the solution was cooled to $0{ }^{\circ} \mathrm{C}$ and potassium bromide was filtered off. Afterwards, an appropriate herbicidal acid (MCPA, Dicamba, $0.02 \mathrm{~mol}$ ) was introduced into the obtained methanolic solution of triazolium dihydroxides. The neutralization reaction was conducted for $1 \mathrm{~h}$ at $25^{\circ} \mathrm{C}$. Then, the synthesized DILs were purified by addition of anhydrous acetone $(20 \mathrm{~mL})$ and the residual precipitate was filtered. Finally, the solvent was evaporated and products were dried under reduced pressure at $60{ }^{\circ} \mathrm{C}$ for $24 \mathrm{~h}$.

\section{Tetramethylene-1,4-bis[1-(4-chlorophenyl)-4,4-di- methyl-3-(1H-1,2,4-triazol-1-ylmethyl)-3-pentanol] di[(4-chloro-2-methylphenoxy)acetate] (1a)}

${ }^{1} \mathrm{H}$ NMR (DMSO- $\left.d_{6}, 300 \mathrm{MHz}\right) \delta(\mathrm{ppm})=0.96(\mathrm{~s}, 18 \mathrm{H})$, 1.57-1.81 (m, 4H), 1.88 (br. s, 4H), $2.13(\mathrm{~s}, 6 \mathrm{H}), 2.20$ (m,
2H), 2.58-2.67 (m, 2H), 4.21 (s, 4H), 4.39 (br. s, 4H), 4.54 (br. s, $4 \mathrm{H}), 6.69(\mathrm{~d}, J=8.7 \mathrm{~Hz}, 2 \mathrm{H}), 7.05(\mathrm{dd}, J=8.7,2.7 \mathrm{~Hz}$, 2H), 7.11 (d, $J=2.7 \mathrm{~Hz}, 2 \mathrm{H}), 7.17$ (d, $J=8.4 \mathrm{~Hz}, 4 \mathrm{H}), 7.28$ (d, $J=8.4 \mathrm{~Hz}, 4 \mathrm{H}), 9.49$ (s, 2H), 10.85 (s, 2H); ${ }^{13} \mathrm{C}$ NMR $\left(\right.$ DMSO- $\left.d_{6}, 75 \mathrm{MHz}\right) \delta(\mathrm{ppm})=16.0,25.4,25.5,25.6,29.7$, 36.6, 38.1, 46.4, 56.2, 68.2, 74.8, 112.8, 122.7, 125.9, 127.9, $128.2,129.4,130.0,130.2,141.6,144.0,144.6,156.1$, 170.8; calcd (\%) for $\mathrm{C}_{54} \mathrm{H}_{68} \mathrm{Cl}_{4} \mathrm{~N}_{6} \mathrm{O}_{8}(M=1070.97)$ : $\mathrm{C} 60.56$, H 6.40, N 7.85; found: C 60.31, H 6.62, N 7.56.

\section{Hexamethylene-1,6-bis[1-(4-chlorophenyl)-4,4-di- methyl-3-(1H-1,2,4-triazol-1-ylmethyl)-3-pentanol] di[(4-chloro-2-methylphenoxy)acetate] (2a)}

${ }^{1} \mathrm{H}$ NMR (DMSO- $\left.d_{6}, 300 \mathrm{MHz}\right) \delta(\mathrm{ppm})=0.96(\mathrm{~s}$, $18 \mathrm{H}), 1.24$ (br. s, $4 \mathrm{H}), 1.57-1.80(\mathrm{~m}, 8 \mathrm{H}), 2.13(\mathrm{~m}, 8 \mathrm{H})$, 2.56-2.66 (m, 2H), 4.25-4.31 (m, 8H), $4.55(\mathrm{~m}, 4 \mathrm{H}), 6.69$ $(\mathrm{d}, J=8.7 \mathrm{~Hz}, 2 \mathrm{H}), 7.05(\mathrm{dd}, J=8.7,2.7 \mathrm{~Hz}, 2 \mathrm{H}), 7.12$ (d, $J=2.7 \mathrm{~Hz}, 2 \mathrm{H}), 7.16(\mathrm{~d}, J=8.4 \mathrm{~Hz}, 4 \mathrm{H}), 7.28(\mathrm{~d}, J=8.4 \mathrm{~Hz}$, $4 \mathrm{H}), 9.48(\mathrm{~s}, 2 \mathrm{H}), 10.86(\mathrm{~s}, 2 \mathrm{H}) ;{ }^{13} \mathrm{C}$ NMR (DMSO- $d_{6}$, $75 \mathrm{MHz}) \delta(\mathrm{ppm})=16.0,24.4,25.5(3 \mathrm{C}), 28.5,29.6,36.5$, $38.1,47.2,56.3,68.1,74.7,112.8,122.8,125.9,127.9$, $128.2,129.5,130.0,130.3,141.6,144.0,144.5,156.0$, 170.8; calcd (\%) for $\mathrm{C}_{56} \mathrm{H}_{72} \mathrm{Cl}_{4} \mathrm{~N}_{6} \mathrm{O}_{8}(M=1099.03)$ : C 61.20, H 6.60, N 7.65; found: C 61.49, H 6.33, N 7.88.

Octamethylene-1,8-bis[1-(4-chlorophenyl)-4,4-dimethyl-3-(1H-1,2,4-triazol-1-ylmethyl)-3-pentanol] di[(4-chloro-2-methylphenoxy)acetate] (3a)

${ }^{1} \mathrm{H}$ NMR (DMSO- $\left.d_{6}, 400 \mathrm{MHz}\right) \delta(\mathrm{ppm})=0.96(\mathrm{~s}, 18 \mathrm{H})$, 1.17 (br. s, $8 \mathrm{H}), 1.57-1.80(\mathrm{~m}, 8 \mathrm{H}), 2.01-2.08(\mathrm{~m}, 2 \mathrm{H})$, $2.13(\mathrm{~s}, 6 \mathrm{H}), 2.56-2.63(\mathrm{~m}, 2 \mathrm{H}), 4.19(\mathrm{~s}, 4 \mathrm{H}), 4.27(\mathrm{~m}, 4 \mathrm{H})$, $4.52-4.61(\mathrm{~m}, 4 \mathrm{H}), 6.68(\mathrm{~d}, J=8.8 \mathrm{~Hz}, 2 \mathrm{H}), 7.03(\mathrm{dd}, J=8.8$, $2.8 \mathrm{~Hz}, 2 \mathrm{H}), 7.11(\mathrm{~d}, J=2.6 \mathrm{~Hz}, 2 \mathrm{H}), 7.15(\mathrm{~d}, J=8.2 \mathrm{~Hz}$, $4 \mathrm{H}), 7.28(\mathrm{~d}, J=8.2 \mathrm{~Hz}, 4 \mathrm{H}), 9.46(\mathrm{~s}, 2 \mathrm{H}), 10.91(\mathrm{~s}, 2 \mathrm{H})$; ${ }^{13} \mathrm{C}$ NMR (DMSO- $\left.d_{6}, 100 \mathrm{MHz}\right) \delta(\mathrm{ppm})=16.0,25.2,25.5$, 27.9, 28.8, 29.6, 36.4, 38.1, 47.3, 56.4, 68.3, 74.7, 112.8, $122.5,125.8,127.8,128.1,129.4,130.0,130.2,141.6$, 144.0, 144.5, 156.1, 170.6; calcd (\%) for $\mathrm{C}_{58} \mathrm{H}_{76} \mathrm{Cl}_{4} \mathrm{~N}_{6} \mathrm{O}_{8}$ $(M=1127.08)$ : C 61.81, H 6.80, N 7.46; found: C 61.57, H 7.03, N 7.25.

\section{Decamethylene-1,10-bis[1-(4-chlorophenyl)-4,4-di- methyl-3-(1H-1,2,4-triazol-1-ylmethyl)-3-pentanol] di[(4-chloro-2-methylphenoxy)acetate] (4a)}

${ }^{1} \mathrm{H}$ NMR (DMSO- $\left.d_{6}, 400 \mathrm{MHz}\right) \delta(\mathrm{ppm})=0.97(\mathrm{~s}, 18 \mathrm{H})$, $1.12-1.17(\mathrm{~m}, 12 \mathrm{H}), 1.59-1.67(\mathrm{~m}, 8 \mathrm{H}), 2.02-2.10(\mathrm{~m}$, $2 \mathrm{H}), 2.14$ (s, 6H), 2.56-2.63 (m, 2H), $4.27(\mathrm{~m}, 8 \mathrm{H}), 4.56$ $(\mathrm{m}, 4 \mathrm{H}), 6.70(\mathrm{~d}, J=8.8 \mathrm{~Hz}, 2 \mathrm{H}), 7.05(\mathrm{dd}, J=8.7,2.7 \mathrm{~Hz}$, $2 \mathrm{H}), 7.13(\mathrm{~d}, J=2.6 \mathrm{~Hz}, 2 \mathrm{H}), 7.15(\mathrm{~d}, J=8.4 \mathrm{~Hz}, 4 \mathrm{H})$, $7.28(\mathrm{~d}, J=8.4 \mathrm{~Hz}, 4 \mathrm{H}), 9.42(\mathrm{~s}, 2 \mathrm{H}), 10.79(\mathrm{~s}, 2 \mathrm{H}) ;{ }^{13} \mathrm{C}$ 
NMR $\left(\mathrm{DMSO}-d_{6}, 100 \mathrm{MHz}\right) \delta(\mathrm{ppm})=16.0,25.4(2 \mathrm{C})$, 25.5 (2C), 28.3, 28.7, 29.0, 29.6, 36.5, 38.1, 47.4, 56.4, $67.7,74.7,112.8,122.8,125.9,127.9,128.1,129.5,130.0$, 130.2 , 141.6, 143.9, 144.4, 155.9, 170.6; calcd $(\%)$ for $\mathrm{C}_{60} \mathrm{H}_{80} \mathrm{Cl}_{4} \mathrm{~N}_{6} \mathrm{O}_{8}(M=1155.13): \mathrm{C} 62.39, \mathrm{H}$ 6.98, N 7.28; found: C 62.12, H 6.77, N 7.43.

\section{Dodecamethylene-1,12-bis[1-(4-chlorophenyl)-4,4-di- methyl-3-(1H-1,2,4-triazol-1-ylmethyl)-3-pentanol] di[(4-chloro-2-methylphenoxy)acetate] (5a)}

${ }^{1} \mathrm{H}$ NMR (DMSO- $\left.d_{6}, 400 \mathrm{MHz}\right) \delta(\mathrm{ppm})=0.97(\mathrm{~s}, 18 \mathrm{H})$, $1.12-1.18(\mathrm{~m}, 16 \mathrm{H}), 1.61-1.82(\mathrm{~m}, 8 \mathrm{H}), 1.98-2.07(\mathrm{~m}$, $2 \mathrm{H}), 2.15(\mathrm{~s}, 6 \mathrm{H}), 2.56-2.64(\mathrm{~m}, 2 \mathrm{H}), 4.22(\mathrm{~s}, 4 \mathrm{H}), 4.30$ $(\mathrm{m}, 4 \mathrm{H}), 4.52-4.63(\mathrm{~m}, 4 \mathrm{H}), 6.70(\mathrm{~d}, J=8.8 \mathrm{~Hz}, 2 \mathrm{H}), 7.03$ (dd, $J=8.7,2.6 \mathrm{~Hz}, 2 \mathrm{H}), 7.11(\mathrm{~d}, J=2.6 \mathrm{~Hz}, 2 \mathrm{H}), 7.15$ (d, $J=8.4 \mathrm{~Hz}, 4 \mathrm{H}), 7.27$ (d, $J=8.4 \mathrm{~Hz}, 4 \mathrm{H}), 9.49$ (s, 2H), 10.95 $(\mathrm{s}, 2 \mathrm{H}) ;{ }^{13} \mathrm{C}$ NMR (DMSO- $\left.d_{6}, 100 \mathrm{MHz}\right) \delta(\mathrm{ppm})=16.0$, 25.4, 25.5 (2C), 28.4, 28.9, 29.0, 29.6, 36.4, 38.1, 47.4, 56.5, 68.2, 74.7, 112.8, 122.8, 125.8, 127.8, 128.1, 129.4, 130.0, 130.2, 141.6, 144.0, 144.5, 156.1, 170.8; calcd (\%) for $\mathrm{C}_{62} \mathrm{H}_{84} \mathrm{Cl}_{4} \mathrm{~N}_{6} \mathrm{O}_{8}(M=1183.19)$ : C 62.94, H 7.16, N 7.10; found: C 63.16, H 6.95, N 7.30.

Tetramethylene-1,4-bis[1-(4-chlorophenyl)-4,4-dimethyl-3-(1H-1,2,4-triazol-1-ylmethyl)-3-pentanol] di[3,6-dichloro-2-methoxybenzoate] (1 b)

${ }^{1} \mathrm{H}$ NMR (DMSO- $\left.d_{6}, 300 \mathrm{MHz}\right) \delta(\mathrm{ppm})=0.97(\mathrm{~s}, 18 \mathrm{H})$, 1.55-1.81 (m, 4H), 1.95 (br. s, 4H), 2.18-2.28 (m, 2H), 2.59-2.69 (m, 2H), 3.78 (s, 6H), 4.46 (br. s, 4H), 4.55 (br. s, 4H), $7.04(\mathrm{~d}, J=8.6 \mathrm{~Hz}, 2 \mathrm{H}), 7.16-7.20(\mathrm{~m}, 6 \mathrm{H}), 7.28$ $(\mathrm{d}, J=8.4 \mathrm{~Hz}, 4 \mathrm{H}), 9.50(\mathrm{~s}, 2 \mathrm{H}), 10.70(\mathrm{~s}, 2 \mathrm{H}) ;{ }^{13} \mathrm{C} \mathrm{NMR}$ $\left(\right.$ DMSO- $\left.d_{6}, 75 \mathrm{MHz}\right) \delta(\mathrm{ppm})=25.4,25.5,25.6,29.7,36.6$, $38.0,46.5,56.1,61.0,74.8,125.1,125.2,126.7,127.5$, $128.1,130.0,130.2,140.7,141.6,144.1,144.4,151.1$, 165.9; calcd (\%) for $\mathrm{C}_{52} \mathrm{H}_{62} \mathrm{Cl}_{6} \mathrm{~N}_{6} \mathrm{O}_{8}(M=1111.80)$ : C 56.18, H 5.62, N 7.56; found: C 56.31, H 5.89, N 7.77.

\section{Hexamethylene-1,6-bis[1-(4-chlorophenyl)-4,4-di- methyl-3-(1H-1,2,4-triazol-1-ylmethyl)-3-pentanol] di[3,6-dichloro-2-methoxybenzoate] (2b)}

${ }^{1} \mathrm{H}$ NMR (DMSO- $\left.d_{6}, 300 \mathrm{MHz}\right) \delta(\mathrm{ppm})=0.98(\mathrm{~s}, 18 \mathrm{H})$, 1.28 (br. s, 4H), 1.58-1.85 (m, 8H), 1.95 (br. s, 4H), 2.12-2.22 (m, 2H), 2.59-2.69 (m, 2H), 3.79 (s, 6H), 4.33 (m, 4H), 4.59 (br. s, 4H), 7.05 (d, J=8.7 Hz, 2H), 7.16-7.20 (m, $6 \mathrm{H}), 7.28(\mathrm{~d}, J=8.4 \mathrm{~Hz}, 4 \mathrm{H}), 9.50(\mathrm{~s}, 2 \mathrm{H}), 10.72(\mathrm{~s}, 2 \mathrm{H}) ;{ }^{13} \mathrm{C}$ NMR (DMSO- $\left.d_{6}, 75 \mathrm{MHz}\right) \delta(\mathrm{ppm})=24.5,25.5$ (2C), 28.6, 29.7, 36.5, 38.1, 47.2, 56.2, 61.0, 74.8, 125.1, 125.2, 126.8, $127.4,128.1,130.0,130.2,140.5,141.6,144.1,144.3$, 151.1, 166.0; calcd (\%) for $\mathrm{C}_{54} \mathrm{H}_{66} \mathrm{Cl}_{6} \mathrm{~N}_{6} \mathrm{O}_{8}(M=1139.86)$ : C 56.90, H 5.84, N 7.37; found: C 57.14, H 6.07, N 7.56.
Octamethylene-1,8-bis[1-(4-chlorophenyl)-4,4-dimethyl-3-(1H-1,2,4-triazol-1-ylmethyl)-3-pentanol] di[3,6-dichloro-2-methoxybenzoate] (3c)

${ }^{1} \mathrm{H}$ NMR (DMSO- $\left.d_{6}, 400 \mathrm{MHz}\right) \delta(\mathrm{ppm})=0.99(\mathrm{~s}, 18 \mathrm{H})$, 1.19 (br. s, 8H), 1.61-1.68 (m, 2H), 1.74-1.82 (m, 6H), 2.10-2.18 (m, 2H), 2.60-2.67 (m, 2H), $3.80(\mathrm{~s}, 6 \mathrm{H}), 4.32$ (m, 4H), 4.61 (br. s, 4H), 7.05 (d, J=8.5 Hz, 2H), 7.16-7.20 $(\mathrm{m}, 6 \mathrm{H}), 7.29$ (d, $J=8.5 \mathrm{~Hz}, 4 \mathrm{H}), 9.48(\mathrm{~s}, 2 \mathrm{H}), 10.71(\mathrm{~s}, 2 \mathrm{H})$; ${ }^{13} \mathrm{C}$ NMR (DMSO- $\left.d_{6}, 100 \mathrm{MHz}\right) \delta(\mathrm{ppm})=25.3,25.5(3 \mathrm{C})$, 28.0, 28.9, 29.6, 36.5, 38.1, 47.4, 56.4, 61.0, 74.8, 125.1, $125.3,126.7,127.5,128.1,130.0,130.2,140.6,141.6$, 144.1, 144.3, 151.1, 165.9; calcd (\%) for $\mathrm{C}_{56} \mathrm{H}_{70} \mathrm{Cl}_{6} \mathrm{~N}_{6} \mathrm{O}_{8}$ $(M=1167.91)$ : C 57.59, H 6.04, N 7.20; found: C 57.31, H $6.30, \mathrm{~N} 7.44$.

Decamethylene-1,10-bis[1-(4-chlorophenyl)-4,4-dimethyl-3-(1H-1,2,4-triazol-1-ylmethyl)-3-pentanol] di[3,6-dichloro-2-methoxybenzoate] (4b)

${ }^{1} \mathrm{H}$ NMR (DMSO- $\left.d_{6}, 400 \mathrm{MHz}\right) \delta(\mathrm{ppm})=0.99(\mathrm{~s}, 18 \mathrm{H})$, $1.13-1.19(\mathrm{~m}, 12 \mathrm{H}), 1.60-1.68(\mathrm{~m}, 2 \mathrm{H}), 1.74-1.84(\mathrm{~m}$, $6 \mathrm{H}), 2.10-2.18(\mathrm{~m}, 2 \mathrm{H}), 2.59-2.67(\mathrm{~m}, 2 \mathrm{H}), 3.79(\mathrm{~s}, 6 \mathrm{H})$, 4.32 (m, 4H), 4.61 (br. s, 4H), 7.09 (d, J=8.6 Hz, 2H), $7.18(\mathrm{~d}, J=8.5 \mathrm{~Hz}, 2 \mathrm{H}), 7.24(\mathrm{~d}, J=8.6 \mathrm{~Hz}, 4 \mathrm{H}), 7.29$ $(\mathrm{d}, J=8.6 \mathrm{~Hz}, 4 \mathrm{H}), 9.44(\mathrm{~s}, 2 \mathrm{H}), 10.62(\mathrm{~s}, 2 \mathrm{H}) ;{ }^{13} \mathrm{C} \mathrm{NMR}$ $\left(\mathrm{DMSO}-d_{6}, 100 \mathrm{MHz}\right) \delta(\mathrm{ppm})=25.4,25.5,28.3,28.7,29.0$, 29.6, 36.5, 38.1, 47.5, 56.3, 61.0, 74.8, 125.2, 125.3, 127.4, $127.5,128.1,130.0,130.2,139.2,141.5,144.0,144.2$, 151.3, 165.9; calcd (\%) for $\mathrm{C}_{58} \mathrm{H}_{74} \mathrm{Cl}_{6} \mathrm{~N}_{6} \mathrm{O}_{8}(M=1195.96)$ : C 58.25, H 6.24, N 7.03; found: C 58.01, H 6.41, N 7.26.

Dodecamethylene-1,12-bis[1-(4-chlorophenyl)-4,4-dimethyl-3-(1H-1,2,4-triazol-1-ylmethyl)-3-pentanol] di[3,6-dichloro-2-methoxybenzoate] (5b)

${ }^{1} \mathrm{H}$ NMR (DMSO- $\left.d_{6}, 400 \mathrm{MHz}\right) \delta(\mathrm{ppm})=0.99(\mathrm{~s}, 18 \mathrm{H})$, $1.13-1.20$ (m, 16H), 1.61-1.69 (m, 2H), 1.74-1.85 (m, 6H), 2.07-2.13 (m, 2H), 2.59-2.66 (m, 2H), $3.80(\mathrm{~s}, 6 \mathrm{H}), 4.33$ $(\mathrm{m}, 4 \mathrm{H}), 4.61(\mathrm{~m}, 4 \mathrm{H}), 7.05(\mathrm{~d}, J=8.4 \mathrm{~Hz}, 2 \mathrm{H}), 7.16-7.20$ $(\mathrm{m}, 6 \mathrm{H}), 7.28(\mathrm{~d}, J=8.4 \mathrm{~Hz}, 4 \mathrm{H}), 9.48(\mathrm{~s}, 2 \mathrm{H}), 10.74(\mathrm{~s}$, $2 \mathrm{H}) ;{ }^{13} \mathrm{C}$ NMR (DMSO- $\left.d_{6}, 100 \mathrm{MHz}\right) \delta(\mathrm{ppm})=25.4,25.5$ (2C), 28.4, 28.8, 28.9, 29.0, 29.6, 36.5, 38.1, 47.5, 56.4, $61.0,74.8,125.1,125.2,126.7,127.5,128.1,130.0,130.2$, $140.5,141.6,144.0,144.3,151.2,165.9$; calcd (\%) for $\mathrm{C}_{60} \mathrm{H}_{78} \mathrm{Cl}_{6} \mathrm{~N}_{6} \mathrm{O}_{8}(M=1224.02)$ : C 58.88, H 6.42, N 6.87; found: C 58.59, H 6.13, N 7.08.

\section{Antifungal activity}

Six species of fungi obtained from the Institute of Plant Protection-NRI collection were used: Sclerotinia sclerotiorum, Botrytis cinerea, Fusarium culmorum, Fusarium 
oxysporum, Colletotrichum sp., and Monographella nivalis. The sample of tested DILs was dissolved in $4 \mathrm{~mL}$ of methanol, then added to a sterile medium cooled to $50{ }^{\circ} \mathrm{C}$ (PDA- potato dextrose agar, Difco $\left.{ }^{\mathrm{TM}}\right)$. The concentration of the studied salt in the medium was 10,100 or $1000 \mathrm{ppm}$. Liquid medium containing the tested salts was distributed on the Petri dishes (diameter of $50 \mathrm{~mm}$ ). The $4 \mathrm{~mm}$ disks of the examined fungi were placed in the center of the Petri dish. In the control sample, the fungi were grown on PDA with the addition of sterile solvent. The tested salts were compared with the commercial fungicide Tebu $250 \mathrm{EW}$ containing tebuconazole as an active substance. The plates were incubated at room temperature until the mycelium in the control reached the edge of the Petri dish. Afterwards, the diameter of the mycelium was measured, subtracting the initial diameter of the disk with the fungus $(4 \mathrm{~mm})$. Three replications were performed for each experimental sample. The results were subjected to Student-Newman-Keuls's analysis to test for significant differences between control and samples with addition of DILs. Fungicidal activity was calculated on the basis of the following equation:

$\%$ activity $=\left(\frac{A-B}{A}\right) \cdot 100 \%$,

where $A$ is diameter of the mycelium without addition of tested substances and $B$ is diameter of the mycelium with addition of tested substances.

\section{Herbicidal activity}

The activity of the prepared DILs was tested on common lambsquarters and oilseed rape. Seeds were sown into pots $(0.5 \mathrm{~L})$ and kept in a greenhouse at the temperature of $20^{\circ} \mathrm{C}$, humidity of $60 \%$ and photoperiod $16 / 8 \mathrm{~h}$ (day/night). The plants were treated by the herbicide at 6 leaves growth stage (BBCH 16). A spray solution was prepared by dissolving the synthesized salts in a mixture of water and ethanol $(1: 1 \mathrm{v} / \mathrm{v})$ at the amount corresponding to the dose $400 \mathrm{~g}$ of MCPA or $200 \mathrm{~g}$ dicamba per $1 \mathrm{ha}$. Commercial herbicides: Chwastox Extra $300 \mathrm{SL}$ ( $300 \mathrm{~g}$ of sodium and potassium salts of MCPA in $1 \mathrm{~L}$ ) and Dikamba $480 \mathrm{SL}$ ( $480 \mathrm{~g}$ Dicamba in $1 \mathrm{~L}$ ) were chosen as references. All the treatments were applied using a moving sprayer (APORO, Poznan, Poland) with TeeJet 110/02 at-fan nozzles (TeeJet Technologies, Wheaton, IL, USA) delivering $200 \mathrm{~L}$ of spray solution per 1 ha at $0.2 \mathrm{MPa}$ pressure. The distance from the nozzles to the tips of the plant was equal to approx. $40 \mathrm{~cm}$. The study was carried out in four replications in a randomized setup. After application, the plants were placed again in a greenhouse under the above-mentioned environmental conditions. A weed control was evaluated visually 2 weeks after the treatment using a scale of 0 (no effect) to $100 \%$ (complete weed destruction).

\section{Results and discussion}

A three-step method for the synthesis of new DILs is shown in Scheme 1. Preparation of precursors in the form of triazolium dibromides (1-5) was the first part of the synthesis.

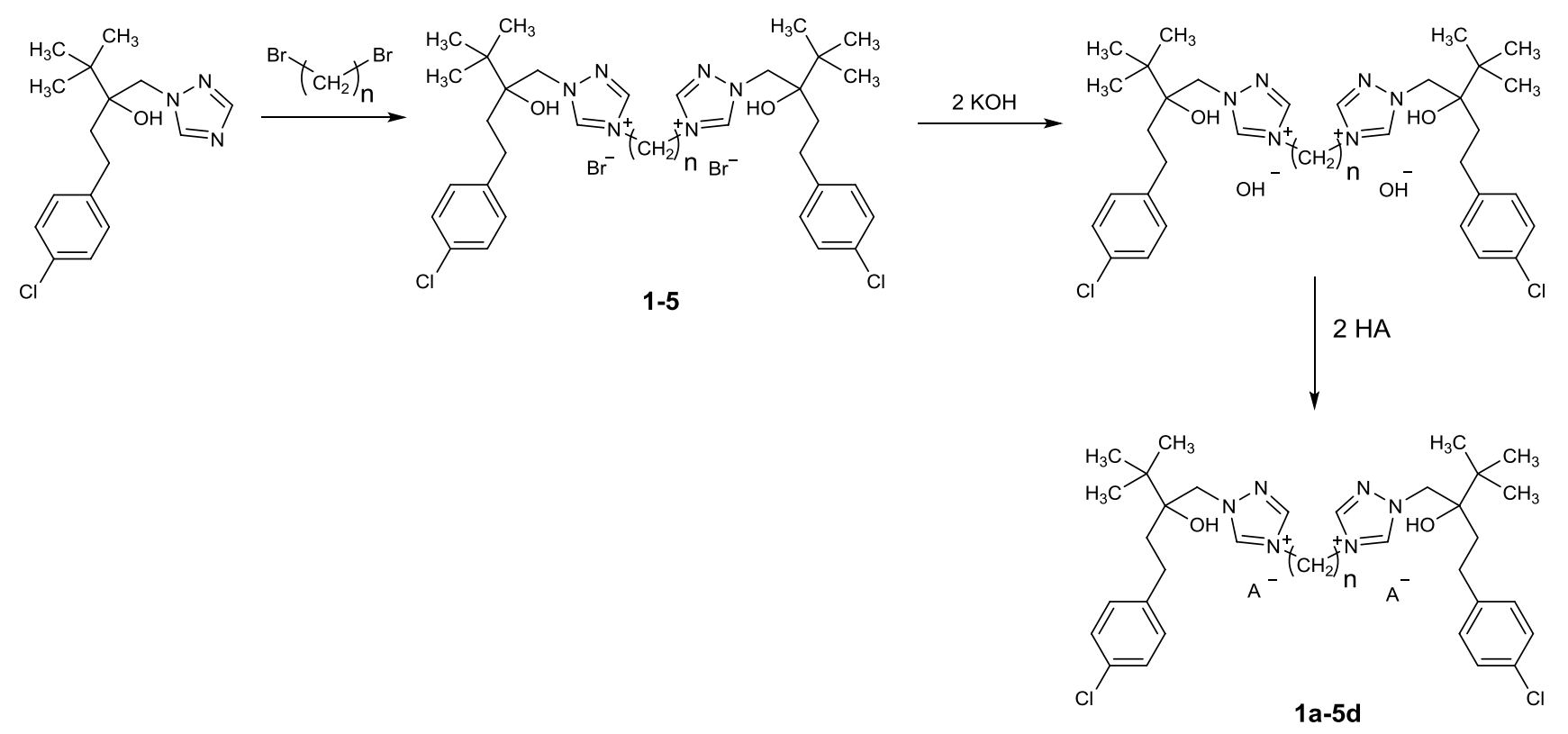

Scheme 1 Preparation of dibromide salts (1-5) and dicationic ILs (1a-5d) 
Table 1 Prepared triazolium dibromides

\begin{tabular}{llll}
\hline Bromide & $n$ & Yield $(\%)$ & $T_{\mathrm{m}}\left({ }^{\circ} \mathrm{C}\right)$ \\
\hline 1 & 4 & 93 & $218-220$ \\
2 & 6 & 87 & $155-156$ \\
3 & 8 & 94 & $236-237$ \\
4 & 10 & 98 & $140-142$ \\
5 & 12 & 90 & $180-181$ \\
\hline
\end{tabular}

Table 2 Synthesized triazolebased DILs

\begin{tabular}{llll}
\hline ILs & $n$ & A & Yield (\%) \\
\hline 1a & 4 & MCPA & 93 \\
2a & 6 & MCPA & 97 \\
3a & 8 & MCPA & 94 \\
4a & 10 & MCPA & 95 \\
$5 \mathrm{a}$ & 12 & MCPA & 92 \\
$1 \mathrm{~b}$ & 4 & Dicamba & 98 \\
2b & 6 & Dicamba & 95 \\
3b & 8 & Dicamba & 97 \\
4b & 10 & Dicamba & 94 \\
$5 \mathrm{~b}$ & 12 & Dicamba & 95 \\
\hline
\end{tabular}

The quaternization of the nitrogen atom in the $\mathrm{N}-4$ position using acetonitrile as a solvent was carried out according to the modified method described by Jin et. al (2006). The quaternization agents were dibromoalkanes with an alkyl chain length of 4-12 carbon atoms. In addition, tebuconazole possessing a 1,2,4-triazole group functionalized in the $\mathrm{N}-1$ position was used as the triazole compound in the quaternization reaction. The results of the precursor synthesis are shown in Table 1.

All the obtained triazolium dibromides were in the form of white solids with a high melting point $\left(T_{\mathrm{m}}\right)$. The highest values were measured for the bromides with the linker containing 4 and 8 methylene groups and were approximately at 217 and $235{ }^{\circ} \mathrm{C}$, respectively. For the remaining bromides, $T_{\mathrm{m}}$ was below $200{ }^{\circ} \mathrm{C}$ and ranged from 140 to $180{ }^{\circ} \mathrm{C}$. Lowest value was measured for bromide 4 . The efficiency of the first stage was equal to or exceeded $87 \%$.

After purification and drying, the obtained triazolium bromides were used as a substrate in the second step of the synthesis, in the exchange of bromide anions to hydroxides according to the methodology described earlier for herbicidal DILs (Niu et al. 2018; Niemczak et al. 2015). The obtained methanolic solutions of the precursor in the form of hydroxides were used in the last stage of the method, in the neutralization reaction using two selected herbicidal acids: 2-methyl-4-chlorophenoxyacetic acid (MCPA) and 3,6-dichloro-2-methoxybenzoic acid (Dicamba). The applied method of synthesis was characterized by a high yield ranging from 91 to $98 \%$ (Table 2).
Triazolium DILs with the Dicamba anion were amorphous, noncrystalline solids and compounds (1-5a) based on the MCPA were in the form of waxes.

All synthesized DILs exhibited low solubility in water. On the other hand, the obtained compounds displayed excellent solubility in polar solvents such as methanol or DMSO. In addition, solubility was not observed in hexane and toluene.

The chemical structures of the obtained ILs were confirmed by analysis of ${ }^{1} \mathrm{H}$ and ${ }^{13} \mathrm{C}$ NMR spectra. In the case of a linker chain, protons of the methyl group adjacent to the $\mathrm{N}-4$ nitrogen occurred at approx. $4.30 \mathrm{ppm}$. The remaining signals of the linker were present at 1.82 , and its extension caused the appearance of additional peaks of methylene groups in the form of wide singlets at approx. 1.26 (ILs $\mathbf{2 a}, \mathbf{2 b}$ ), 1.17 (ILs 3a, 3b) and two peaks in the range of 1.11-1.21 in the case of other DILs. The signals of protons in the form of a doublet derived from the aromatic ring appeared in all spectra at 7.17 and 7.28 ppm. In addition, the presence of the tert-butyl group was confirmed by the signals at approx. $0.96 \mathrm{ppm}$. The protons of the methylene group located on the N-1 nitrogen of the triazole group were present in all spectra in the range 4.48-4.62 ppm. Furthermore, the remaining protons of methylene groups adjacent to the aromatic ring and tert-butyl group occurred in the form of separated signals at approx. 2.16 and 2.62, and also in the range of 1.57-1.82, overlapping with the signal derived from the linker chain. The changes in the chemical shift of the H-3 and H-5 proton signals are presented in Table S7. The quaternization reaction resulted in a strong shift of the two singlets derived from the protons of the triazole group in comparison to the pure tebuconazole (7.95 and $8.19 \mathrm{ppm}$, spectrum in $\mathrm{CDCl}_{3}$ ) due to the redistribution of electron density (Golubyatnikova et al. 2012). For the obtained DILs, the proton $\mathrm{H}-3$ was determined in the range 9.42-9.50 ppm, and the signal from the proton $\mathrm{H}-5$ appeared in the range 10.62-10.95 ppm. The highest values of proton chemical shifts occurred for DILs 1-5a in the case of an anion derived from MCPA acid. In addition, the extension of the linker resulted in slight changes in the chemical shift values, however, regardless of the type of anion, the lowest value in the group was caused by the linker with ten carbon atoms.

Properties of synthesized ILs (glass transition and decomposition temperatures) are shown in Table 3 . The $T_{\text {onset5 }}$ values for triazolium DILs were observed in the range from 201 to $223^{\circ} \mathrm{C}$. Generally, it was found that the trend of the anions on the stability can be described as follows: MCPA > Dicamba. A similar relationship also occurred for the previously described dicationic HILs (Niemczak et al. 2015). In the case of monocationic HILs, the effect of type of an anion on stability may vary depending on the used cation. However, most of the ILs with Dicamba anion were less stable compared to compounds based on other 
Table 3 Thermal properties of prepared DILs

\begin{tabular}{|c|c|c|c|c|}
\hline ILs & $T_{\mathrm{g}}^{\mathrm{a}}\left({ }^{\circ} \mathrm{C}\right)$ & $T_{\text {onset } 5}{ }^{\mathrm{b}}\left({ }^{\circ} \mathrm{C}\right)$ & $\begin{array}{l}T_{\text {onset50 }}{ }^{\mathrm{c}} \\
\left({ }^{\circ} \mathrm{C}\right)\end{array}$ & $\begin{array}{l}\text { Steps of } \\
\text { degrada- } \\
\text { tion }\end{array}$ \\
\hline $1 \mathrm{a}$ & 20 & 223 & 314 & 2 \\
\hline $2 \mathrm{a}$ & 19 & 209 & 298 & 3 \\
\hline $3 a$ & 15 & 218 & 303 & 2 \\
\hline $4 a$ & 18 & 213 & 322 & 3 \\
\hline $5 \mathrm{a}$ & 10 & 212 & 298 & 3 \\
\hline $1 b$ & 46 & 219 & 281 & 2 \\
\hline $2 b$ & 35 & 203 & 266 & 2 \\
\hline $3 b$ & 38 & 201 & 263 & 2 \\
\hline $4 b$ & 30 & 207 & 306 & 2 \\
\hline $5 b$ & 32 & 201 & 267 & 3 \\
\hline
\end{tabular}

${ }^{\mathrm{a}} T_{\mathrm{g}}$-glass transition temperature

${ }^{\mathrm{b}} T_{\text {onset5 }}$ - decomposition temperature of $5 \%$ sample

${ }^{\mathrm{c}} T_{\text {onset50 }}$-decomposition temperature of $50 \%$ sample

herbicidal acids (Pernak et al. 2016). Analyzing the thermal stability of the obtained DILs with different length of the linker chain, no significant differences were observed between the compounds in the homologue series. The lack of a strong influence of the linker on the thermal stability also occurred for other DILs (Shirota et al. 2011). Analyzes if the decomposition temperatures at which $50 \%$ of weight lost occurred $\left(T_{\text {onset50 }}\right)$ showed that all the ILs were characterized by thermal stability from 263 to $314{ }^{\circ} \mathrm{C}$ and the effect of the anion is the same as in the case $T_{\text {onset } 5}$. The obtained DILs mostly exhibit two or three thermal decomposition steps. In addition, elongation of linker influenced the decomposition behavior and can cause a more complex degradation. Additionally, exothermal effects were observed for all DILs decomposition. The highest values $\left(163 \mathrm{~J} \mathrm{~g}^{-1}\right)$ were measured for IL $1 \mathbf{a}$.

The phase transition of synthesized DILs was evaluated by differential scanning calorimetry (DSC) and only glass transition temperatures $\left(T_{\mathrm{g}}\right)$ were observed in all cases. A previously reported study showed that the length of the alkyl linkage chain has a weak influence on the $T_{\mathrm{g}}$ values (Pitawala et al. 2009). In our work, $T_{\mathrm{g}}$ values of triazolium DILs significantly decrease with the extension of the linker. The lowest values in a given series of compounds occurred in the case of DILs with the length of the chain between cations equal to 12 atoms of carbon. Moreover, the influence of the anion on the $T_{\mathrm{g}}$ is higher than length of linker and the trend of the anions is: Dicamba > MCPA. ILs with the MCPA anion was characterized by the lowest values $\left(T_{\mathrm{g}}=9.9-19.5\right)$.

In contrast to antibacterial studies (Al-Mohammed et al. 2015), there are currently no reports regarding activity of DILs against fungi causing plant diseases. Fungicidal activities of DILs obtained in our work and their precursors (triazolium dibromides) were determined for six species of fungi: Sclerotinia sclerotiorum, Botrytis cinerea, Fusarium culmorum, Fusarium oxysporum, Colletotrichum, and Monographella nivalis. The mentioned fungi are pathogens which infect a wide range of plants, including economically important crops and are responsible for heavy agricultural losses every year. The ascomycete fungus $S$. sclerotiorum may infect more than 400 plant species, including canola, dry bean, sunflowers or lettuce, causing difficult to control diseases commonly known as white mold or Sclerotinia head rot. Yield losses may reach even 50-70\%, depending on the season and region (Di et al. 2016; Dunker and von Tiedemann 2004; Koch et al. 2007). B. cinerea, also known as the gray mold, is a necrotrophic pathogen which infects a wide range of fruit, vegetable and ornamental crops. Due to notable losses in agriculture, this fungus has been considered as the second most dangerous phytopathogen worldwide ( $\mathrm{Li}$ et al. 2016; Dean et al. 2012). Fusarium genus comprises many species which are able to colonize different plants and are one of the most economically important fungi. F. culmorum is the common pathogen of many important plants causing seedling blight, foot rot, and head blight (Wagacha and Muthomi 2007; Baturo-Ciesniewska and Suchorzynska 2011). Similarly, F. oxysporum represents a worldwide widespread species responsible for Fusarium wilt, Fusarium crown and root (McGovern 2015). In addition to diseases caused by Fusarium genus, the serious problem is associated with the production of mycotoxins, including trichothecenes, fumonisins, and zearalenone. Additionally, Colletotrichum sp. and M. nivalis are common pathogens responsible for anthracnose diseases (Taga et al. 2015) and snow mold (Zeun et al. 2013), respectively. In case of results obtained at a concentration of $10 \mathrm{ppm}$ (Fig. 1), the highest activity against $S$. sclerotiorum fungi was observed for DILs containing Dicamba anions and in most cases the efficacy was higher than $90 \%$ or comparable to the reference formulation. Commercial formulation Tebu $250 \mathrm{EW}$ showed activity equal to $91.7 \pm 8.9 \%$. Notably lower results were measured for DILs with bromide and MCPA anions, for which the highest activity was $65.2 \pm 6.6(3)$ and $38.4 \pm 2.3(\mathbf{4 a})$, respectively. $B$. cinerea fungus proved to be more resistant to the triazolium DILs. In the best cases $(\mathbf{4}, \mathbf{5 a})$, the activity reached approx. $80 \%$. In contrast to the tests carried out using $S$. sclerotiorum, the compounds containing the Dicamba anion were less effective. Their activity did not exceed $60 \%$. Analysis of the results of fungicide activity against $F$. culmorum at the lowest concentration of compounds (Fig. 2) showed that the best efficacy was observed in case of compounds with a bromide anion $(88.4 \pm 2.3)$. For the other DILs, only salts derived from MCPA exceeded $80 \%$ activity. In the case of studies performed on Colletotrichum sp. (Fig. 3), similar to the results obtained for F. oxysporum, the type of anion had little effect on the ability of compounds 

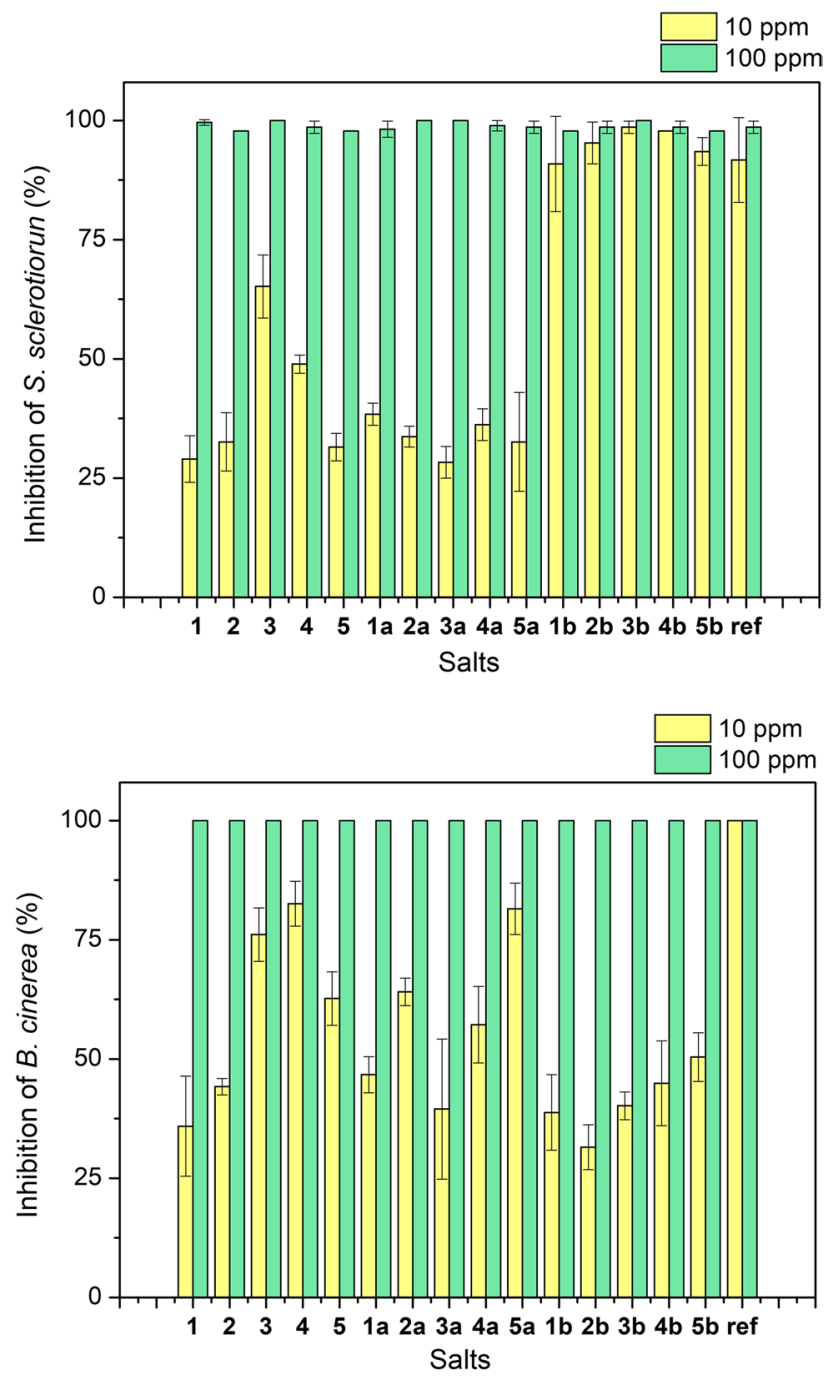

Fig. 1 Fungicidal activity of DILs against Sclerotinia sclerotiorum and Botrytis cinerea

to inhibit fungal growth. The highest results were equal to approx. $70 \%$ at the lowest concentration and activities were much lower compared to the reference compound. The dose of active substance in the amount of $10 \mathrm{ppm}$ was too low in the case of studies carried out using M. nivalis. Five of the tested compounds $(\mathbf{2}, \mathbf{5}, \mathbf{1 a}, \mathbf{1 b}, \mathbf{5 b})$ showed very low activity (less than 20\%) against this fungus. In addition, a pool result of $43.1 \pm 0.6$ was also obtained for the reference formulation. Similar activity was measured for compounds with bromide anions $(\mathbf{3}, \mathbf{4})$, MCPA $(\mathbf{3 a})$ and Dicamba $(\mathbf{3 b})$. However, only for Tebu $250 \mathrm{EW}$ there was an increase of inhibition of fungal growth to $100 \%$ as a result of increasing the concentration to $100 \mathrm{ppm}$. In case of the other compounds, the best result was equal to $92.0 \pm 1.3 \%$ for $\mathbf{4 b}$. Only an increase of the dose of DILs to $1000 \mathrm{ppm}$ allowed to achieve $100 \%$ efficacy.
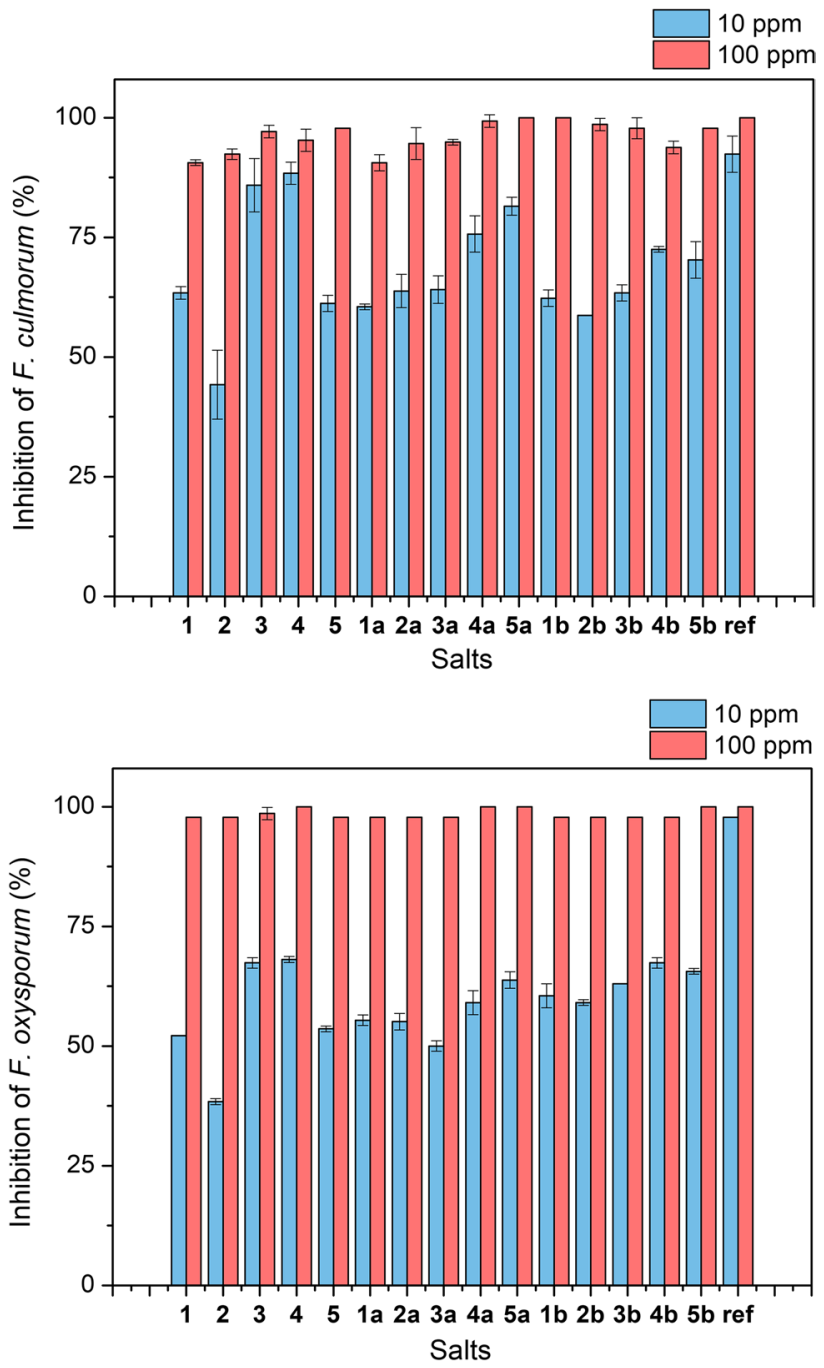

Fig. 2 Fungicidal activity of DILs against Fusarium culmorum and Fusarium oxysporum

Commercial fungicide Tebu $250 \mathrm{EW}$ was used as the reference (ref).

In the previous article (Niemczak et al. 2015), our studies have concentrated on determination the herbicidal activity of DILs with long alkyl chains $\left(\mathrm{C}_{10} \mathrm{H}_{21}\right)$ in the cation. Nevertheless, the results described by Cao et al. (Niu et al. 2018) have shown that the activity of a herbicidal acid such as 2,4-D could be improved by preparation of its dicationic ILs forms without long substituents. In this work, a similar dependence has been demonstrated, namely that DILs with short alkyl substituents exhibited high efficacy, similar to monocation herbicidal ionic liquids. DILs $\mathbf{1 a}$ and $\mathbf{1 b}$ showed the best results (Table 4). In the case of common lambsquarters, higher efficiencies by $20 \%$ compared to commercial products have been demonstrated by these ILs. In the case of oilseed rape, the difference was smaller and amounted to $10 \%$. All the tested DILs have shown better activity than 

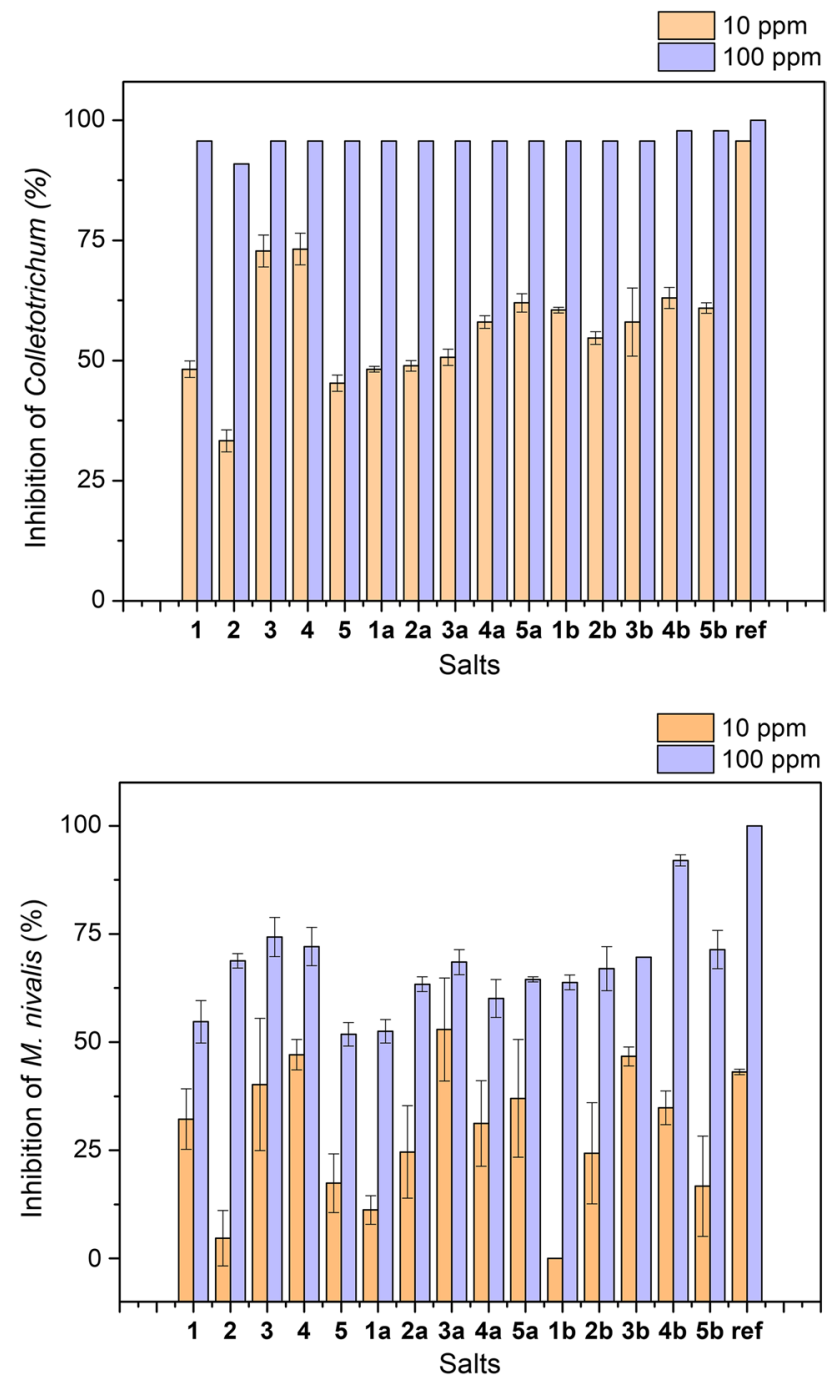

Fig. 3 Fungicidal activity of DILs against Colletotrichum sp. and Monographella nivalis

Table 4 The herbicidal activity of DILs against common lambsquarters and oilseed rape

\begin{tabular}{lll}
\hline Treatment & \multicolumn{2}{l}{ Efficacy $(\%)$} \\
\cline { 2 - 3 } & Lambsquarters & Oilseed rape \\
\hline $\mathbf{1 a}$ & 87 & 55 \\
$\mathbf{2 a}$ & 85 & 55 \\
$\mathbf{3 a}$ & 65 & 45 \\
$\mathbf{4 a}$ & 60 & 50 \\
$\mathbf{5 a}$ & 68 & 45 \\
MCPA reference & 65 & 45 \\
1b & 85 & 38 \\
$\mathbf{2 b}$ & 82 & 35 \\
3b & 80 & 35 \\
4b & 60 & 30 \\
$\mathbf{5 b}$ & 58 & 10 \\
Dicamba reference & 58 & 20 \\
\hline
\end{tabular}

reference herbicides. The herbicidal effect may be improved by the presence of the triazole group in the cation, because triazole inhibits the growth of certain plant species (Yang et al. 2014).

\section{Conclusions}

In summary, it can be established that dicationic triazolium salts show a variety of activities against fungi and plants. Their effectiveness, in the case of fungi, depends primarily on the concentration, but also on the type of anion and the length of the linker. In studies using concentrations between of 100 and 1000 ppm of active substance, most compounds showed efficacy close to the reference substance (tebuconazole). Additionally, the fungicidal activity of the compounds increased with the lengthening of the linker. Mostlly, the highest efficiency occurred for the salts containing linker with 8 and 10 carbon atoms. In addition to the fungicidal activity, the obtained compounds can be applied as herbicides, due to their high biological activity, as demonstrated by tests carried out using common lambsquarters and oil-seed rape. However, the influence of linker length on herbicidal properties is much less notable in comparison to antifungal activity. Regardless of the type of anion, the compounds with the longest linker exhibited the lowest herbicidal efficacy.

Acknowledgements This work was supported by National Science Centre, Poland (Grant no. 2017/25/N/ST5/01657).

Open Access This article is distributed under the terms of the Creative Commons Attribution 4.0 International License (http://creativeco mmons.org/licenses/by/4.0/), which permits unrestricted use, distribution, and reproduction in any medium, provided you give appropriate credit to the original author(s) and the source, provide a link to the Creative Commons license, and indicate if changes were made.

\section{References}

Al-Mohammed NN, Alias Y, Abdullah Z (2015) Tris-imidazolium and benzimidazolium ionic liquids: a new class of biodegradable surfactants. RSC Adv 5:92602-92617. https://doi.org/10.1039/ C4RA14027C

Baturo-Ciesniewska A, Suchorzynska M (2011) Verification of the effectiveness of SCAR (sequence characterized amplified region) primers for the identification of Polish strains of Fusarium culmorum and their potential ability to produce B-trichothecenes and zearalenone. Int J Food Microbiol 148:168-176. https://doi. org/10.1016/j.jifoodmicro.2011.05.017

Bernabò I, Guardia A, Macirella R, Sesti S, Crescente A, Brunelli E (2016) Effects of long-term exposure to two fungicides, pyrimethanil and tebuconazole, on survival and life history traits of Italian tree frog (Hyla intermedia). Aquat Toxicol 172:56-66. https://doi. org/10.1016/j.aquatox.2015.12.017 
Bhatt DR, Maheria KC, Parikh JK (2015) A microwave assisted one pot synthesis of novel ammonium based dicationic ionic liquids. RSC Adv 5:12139-12143. https://doi.org/10.1039/C4RA16251J

Bica K, Rogers RD (2010) Confused ionic liquid ions-a "liquification" and dosage strategy for pharmaceutically active salts. Chem Commun 46:1215-1217. https://doi.org/10.1039/B925147B

Bordagaray A, García-Arrona R, Millán E (2013) Development and application of a screening method for triazole fungicide determination in liquid and fruit samples using solid-phase microextraction and HPLC-DAD. Anal Methods 5:2565-2571. https://doi. org/10.1039/C3AY26433E

Brauer UG, De La Hoz AT, Miller KM (2015) The effect of counteranion on the physicochemical and thermal properties of 4-methyl1-propyl-1,2,4-triazolium ionic liquids. J Mol Liq 210:286-292. https://doi.org/10.1016/j.molliq.2015.02.041

Cano NH, Santiago AN (2014) Arylation of aryl chlorides, a convenient method for the synthesis of new potential triazolic fungicides. Tetrahedron 70:280-285. https://doi.org/10.1016/j.tet.2013.11.067

Chinnappan A, Jadhav AH, Chung W-J, Kim H (2015) Conversion of sugars (sucrose and glucose) into 5-hydroxymethylfurfural in pyridinium based dicationic ionic liquid ([C10(EPy)2]2Br-) with chromium chloride as a catalyst. Ind Crops Prod 76:12-17. https ://doi.org/10.1016/j.indcrop.2015.05.085

Cojocaru OA, Shamshina JL, Gurau G, Syguda A, Praczyk T, Pernak J, Rogers RD (2013) Ionic liquid forms of the herbicide dicamba with increased efficacy and reduced volatility. Green Chem 15:2110-2120. https://doi.org/10.1039/C3GC37143C

Dai Z-C, Chen Y-F, Zhang M, Li S-K, Yang T-T, Shen L, Wang J-X, Qian S-S, Zhu H-L, Ye Y-H (2015) Synthesis and antifungal activity of 1,2,3-triazole phenylhydrazone derivatives. Org Biomol Chem 13:477-486. https://doi.org/10.1039/C4OB01758G

Dean R, Van Kan JA, Pretorius ZA, Hammond-Kosack KE, Di Pietro A, Spanu PD, Rudd JJ, Dickman M, Kahmann R, Ellis J, Foster GD (2012) The top 10 fungal pathogens in molecular plant pathology. Mol Plant Pathol 13:414-430. https://doi.org/10.111 1/j.1364-3703.2011.00783.x

Di Y-L, Zhu Z-Q, Lu X-M, Zhu F-X (2016) Baseline sensitivity and efficacy of trifloxystrobin against Sclerotinia sclerotiorum. Crop Prot 87:31-36. https://doi.org/10.1016/j.cropro.2016.04.020

Ding G, Liu Y, Wang B, Punyapitak D, Guo M, Duan Y, Li J, Cao Y (2014) Preparation and characterization of fomesafen ionic liquids for reducing the risk to the aquatic environment. New J Chem 38:5590-5596. https://doi.org/10.1039/C4NJ01186D

Dunker S, von Tiedemann A (2004) Disease yield loss analysis for Sclerotinia stem rot in winter oilseed rape. IOBC 27(19):59-65

Fareghi-Alamdari R, Ghorbani-Zamani F, Zekri N (2016) Synthesis and hypergolic activity evaluation of some new ammonium-imidazolium based ionic liquids. RSC Adv 6:26386-26391. https:// doi.org/10.1039/C6RA01364C

Golubyatnikova LG, Anpilogova GR, Khisamutdinov RA, Murinov YuI (2012) Extraction of hydrochloric and nitric acid with 1-\{[2-(2,4-dichlorophenyl)-4-propyl-1,3-dioxolan-2-yl]-methyl)$1 \mathrm{H}-1,2,4$-triazole and $(R S)$-1-(4-Chlorophenyl)-4,4-dimethyl-3(1H-1,2,4-triazol-1-yl-methyl)-pentan-3-ol. Russ J Gen Chem 82:310-316. https://doi.org/10.1134/S1070363212020223

Han W, Zhong C, Liang L, Sun Y, Guan Y, Wang L, Sun X, Li J (2014) Electrochemical degradation of triazole fungicides in aqueous solution using $\mathrm{TiO}_{2}-\mathrm{NTs} / \mathrm{SnO}_{2}-\mathrm{Sb} / \mathrm{PbO}_{2}$ anode: experimental and DFT studies. Electrochim Acta 130:179-186. https://doi. org/10.1016/j.electacta.2014.02.119

Hough WL, Smiglak M, Rodriguez H, Swatloski RP, Spear SK, Daly DT, Pernak J, Grisel JE, Carliss RD, Soutullo DM, Davis JH, Rogers RD (2007) The third evolution of ionic liquids: active pharmaceutical ingredients. New J Chem 31:1429-1436. https:// doi.org/10.1039/B706677P
Jin C-M, Ye C, Phillips BS, Zabinski JS, Liu X, Liu W, Shreeve JM (2006) Polyethylene glycol functionalized dicationic ionic liquids with alkyl or polyfluoroalkyl substituents as high temperature lubricants. J Mater Chem 16:1529-1535. https://doi.org/10.1039/ B517888F

Koch S, Dunker S, Kleinhenz B, Rõhrig M, Tiedemann A (2007) A crop loss-related forecasting model for sclerotinia stem rot in winter oilseed rape. Phytopathology 97:1186-1194. https://doi. org/10.1094/PHYTO-97-9-1186

Kordala-Markiewicz R, Rodak H, Markiewicz B, Walkiewicz F, Sznajdrowska A, Materna K, Marcinkowska K, Praczyk T, Pernak J (2014) Phenoxy herbicidal ammonium ionic liquids. Tetrahedron 70:4784-4784. https://doi.org/10.1016/j.tet.2014.05.041

Lewandowski P, Kukawka R, Pospieszny H, Śmiglak M (2014) Bifunctional quaternary ammonium salts based on benzo[1,2,3] thiadiazole-7-carboxylate as plant systemic acquired resistance inducers. New J Chem 38:1372-1375. https://doi.org/10.1039/ C3NJ01613G

Li Y, Sun S, Du C, Xu C, Zhang J, Duan C, Zhu Z (2016) A new disease of mung bean caused by Botrytis cinereal. Crop Prot 85:52-56. https://doi.org/10.1016/j.cropro.2016.03.020

Lucas JA, Hawkins NJ, Fraaije BA (2015) The evolution of fungicide resistance. Adv Appl Microbiol 90:29-92. https://doi.org/10.1016/ bs.aambs.2014.09.001

McGovern RJ (2015) Management of tomato diseases caused by Fusarium oxysporum. Crop Prot 73:78-92. https://doi.org/10.1016/j. cropro.2015.02.021

Mehrkesh A, Karunanithi AT (2013) Energetic ionic materials: how green are they? A comparative life cycle assessment study. ACS Sustain Chem Eng 1:448-455. https://doi.org/10.1021/sc3001383

Moumene T, Belarbi EH, Haddad B, Villemin D, Abbas O, Khelifa B, Bresson S (2015) Vibrational spectroscopic study of ionic liquids: comparison between monocationic and dicationic imidazolium ionic liquids. J Mol Struct 1083:179-186. https://doi. org/10.1016/j.molstruc.2014.02.034

Muñoz-Leoz B, Ruiz-Romera E, Antigüedad I, Garbisu C (2011) Tebuconazole application decreases soil microbial biomass and activity. Soil Biol Biochem 43:2176-2183. https://doi.org/10.1016/j. soilbio.2011.07.001

Nagarajan S, Kandasamy E (2014) Reusable 1,2,4-triazolium based brønsted acidic room temperature ionic liquids as catalyst for Mannich base reaction. Catal Lett 144:1507-1514. https://doi. org/10.1007/s10562-014-1312-7

Ngo HX, Garneau-Tsodikova S, Green KD (2016) A complex game of hide and seek: the search for new antifungals. Med Chem Commun 7:1285-1306. https://doi.org/10.1039/C6MD00222F

Niemczak M, Giszter R, Czerniak K, Marcinkowska K, Walkiewicz $\mathrm{F}$ (2015) Bis(ammonium) ionic liquids with herbicidal anions. RSC Adv 5:15487-15493. https://doi.org/10.1039/C4RA16151C

Niemczak M, Biedziak A, Czerniak K, Marcinkowska K (2017) Preparation and characterization of new ionic liquid forms of 2,4-DP herbicide. Tetrahedron 73:7315-7325. https://doi.org/10.1016/j. tet.2017.11.032

Niemczak M, Rzemieniecki T, Sobiech $€$, Skrzypczak G, Praczyk T, Pernak J (2019) Influence of the alkyl chain length on the physicochemical properties and biological activity in a homologous series of dichlorprop-based herbicidal ionic liquids. J Mol Liq 276:431-440. https://doi.org/10.1016/j.molliq.2018.12.013

Niu J, Zhang Z, Tang J, Tang G, Yang J, Wang W, Huo H, Jiang N, Li J, Cao Y (2018) Dicationic Ionic liquids of herbicide 2,4-dichlorophenoxyacetic acid with reduced negative effects on environment. J Agric Food Chem 66:10362-10368. https://doi.org/10.1021/acs. jafc. 8 b02584

Pernak J, Syguda A, Janiszewska D, Materna K, Praczyk T (2011) Ionic liquids with herbicidal anions. Tetrahedron 67:4838-4844. https://doi.org/10.1016/j.tet.2011.05.016 
Pernak J, Niemczak M, Zakrocka K, Praczyk T (2013) Herbicidal ionic liquid with dual-function. Tetrahedron 69:8132-8136. https://doi. org/10.1016/j.tet.2013.07.053

Pernak J, Markiewicz B, Zgoła-Grzeskowiak A, Chrzanowski Ł, Gwiazdowski R, Marcinkowska K, Praczyk T (2014a) Ionic liquids with dual pesticidal function. RSC Adv 4:39751-39754. https ://doi.org/10.1039/C4RA04816D

Pernak J, Niemczak M, Giszter R, Shamshina JL, Gurau G, Cojocaru OA, Praczyk T, Marcinkowska K, Rogers RD (2014b) Glyphosate-based herbicidal ionic liquids with increased efficacy. ACS Sustainable Chem Eng 2:2845-2851. https://doi.org/10.1021/ sc500612y

Pernak J, Markiewicz B, Łęgosz B, Walkiewicz F, Gwiazdowski R, Praczyk T (2015) Known triazole fungicides-a new trick. RSC Adv 5:9695-9702. https://doi.org/10.1039/C4RA12160K

Pernak J, Niemczak M, Chrzanowski Ł, Ławniczak Ł, Fochtman P, Marcinkowska K, Praczyk T (2016) Betaine and carnitine derivatives as herbicidal ionic liquids. Chem Eur J 22:12012-12021. https://doi.org/10.1002/chem.201601952

Piotrowska A, Syguda A, Chrzanowski Ł, Heipieper HJ (2016) Toxicity evaluation of selected ammonium-based ionic liquid forms with MCPP and dicamba moieties on Pseudomonas putida. Chemosphere 144:107-112. https://doi.org/10.1016/j.chemospher e.2016.09.140

Pitawala J, Matic A, Martinelli A, Jacobsson P, Koch V, Croce F (2009) Thermal properties and ionic conductivity of imidazolium bis(trifluoromethanesulfonyl)imide dicationic ionic liquids. J Phys Chem B 113:10607-10610. https://doi.org/10.1021/jp904989s

Reeder ZK, Adler AM, Miller KM (2016) 1-Alkyl-3-methyl-1,2,3-triazolium [NTf2] ionic liquids: synthesis and properties. Tetrahedron Lett 57:206-209. https://doi.org/10.1016/j.tetlet.2015.11.107

Sahu PK, Das SK, Sarkar M (2014) Fluorescence response of a dipolar organic solute in a dicationic ionic liquid (IL): is the behavior of dicationic IL different from that of usual monocationic IL? Phys Chem Chem Phys 16:12918-12928. https://doi.org/10.1039/ C4CP01053A

Serva A, Migliorati V, Lapi A, Aquilanti G, Arcovitod A, D’Angelo P (2016) Structural properties of geminal dicationic ionic liquid/ water mixtures: a theoretical and experimental insight. Phys Chem Chem Phys 18:16544-16554. https://doi.org/10.1039/C6CP0 $1557 \mathrm{C}$

Shamshina JL, Kelley SP, Gurau G, Rogers RD (2015) Chemistry: develop ionic liquid drugs. Nature 528:188-189. https://doi. org/10.1038/528188a

Shirota H, Mandai T, Fukazawa H, Kato T (2011) Comparison between dicationic and monocationic ionic liquids: liquid density, thermal properties, surface tension, and shear viscosity. J Chem Eng Data 56:2453-2459. https://doi.org/10.1021/je2000183

Singh D, Gardas RL (2016) Influence of cation size on the ionicity, fluidity, and physiochemical properties of 1,2,4-triazolium based ionic liquids. J Phys Chem B 120:4834-4842. https://doi. org/10.1021/acs.jpcb.6b03669

Šiviková K, DianovskýJ Holečková B, Galdíková M, Kolesárová V (2013) Assessment of cytogenetic damage in bovine peripheral lymphocytes exposed to in vitro tebuconazole-based fungicide. Chemosphere 92:555-562. https://doi.org/10.1016/j.chemospher e.2013.04.001

Śmiglak M, Kukawka R, Lewandowski P, Pospieszny H (2014) Cationic derivatives of the plant resistance inducer benzo[1,2,3] thiadiazole-7-carbothioic acid S-methyl ester (BTH) as bifunctional ionic liquids. Tetrahedron Lett 55:3565-3568. https://doi. org/10.1016/j.tetlet.2014.04.108
Śmiglak M, Kukawka R, Lewandowski P, Budziszewska M, Obrępalska-Stęplowska A, Krawczyk K, Zwolinska A, Pospieszny H (2016) Dual Functional Salts of benzo[1.2.3]thiadiazole-7-carboxylates as a highly efficient weapon against viral plant diseases. ACS Sustain Chem Eng 4:3344-3351. https://doi.org/10.1021/ acssuschemeng.7b00161

Stamatis N, Antonopoulou M, Konstantinou I (2015) Photocatalytic degradation kinetics and mechanisms of fungicide tebuconazole in aqueous $\mathrm{TiO}_{2}$ suspensions. Catal Today 252:93-99. https://doi. org/10.1016/j.cattod.2014.09.023

Taga M, Tanaka K, Kato S, Kubo Y (2015) Cytological analyses of the karyotypes and chromosomes of three Colletotrichum species, $C$. orbiculare, C. graminicola and C. higginsianum. Fungal Genet Biol 82:238-250. https://doi.org/10.1016/j.fgb.2015.07.013

Tang G, Wang B, Ding G, Zhang W, Liang Y, Fan C, Dong H, Yang J, Kong D, Cao Y (2018) Developing ionic liquid forms of picloram with reduced negative effects on the aquatic environment. Sci Total Environ 616-617:128-129. https://doi.org/10.1016/j.scito tenv.2017.10.288

Wagacha JM, Muthomi JW (2007) Fusarium culmorum: Infection process, mechanisms of mycotoxin production and their role in pathogenesis in wheat. Crop Prot 26:877-885. https://doi.org/10.1016/j. cropro.2006.09.003

Wang W, Zhu J, Tang G, Huo H, Zhang W, Liang Y, Dong H, Yang J, Cao Y (2019) Novel herbicide ionic liquids based on nicosulfuron with increased efficacy. New J Chem 43:827-833. https://doi. org/10.1039/C8NJ05903A

Yang D, Wang N, Yan X, Shi J, Zhang M, Wang Z, Yuan H (2014) Microencapsulation of seed-coating tebuconazole and its effects on physiology and biochemistry of maize seedlings. Colloids Surf B 114:241-246. https://doi.org/10.1016/j.colsurfb.2013.10.014

Yonekura R, Grinstaff MW (2014) The effects of counterion composition on the rheological and conductive properties of mono- and diphosphonium ionic liquids. Phys Chem Chem Phys 16:2060820617. https://doi.org/10.1039/C4CP02594F

Zabielska-Matejuk J, Stangierska A, Kot M (2015) New ammoniumand 1,2,4-triazolium-based ionic liquids for wood preservation. $\mathrm{J}$ Wood Chem Technol 35:178-192. https://doi.org/10.1080/02773 813.2014.909852

Zeun R, Scalliet G, Oostendorp M (2013) Biological activity of sedaxane-a novel broad-spectrum fungicide for seed treatment. Pest Manag Sci 69:527-534. https://doi.org/10.1002/ps.3405

Zhang W, Yuan J (2016) Poly(1-vinyl-1,2,4-triazolium) poly(ionic liquid)s: synthesis and the unique behavior in loading metal ions. Macromol Rapid Commun 37:1124-1129. https://doi. org/10.1002/marc.201600001

Zhang B, Zhang T, Wang Q, Ren T (2015) Microorganism-based monodisperse microcapsules: encapsulation of the fungicide tebuconazole and its controlled release properties. RSC Adv 5:25164-25170. https://doi.org/10.1039/C5RA01629K

Zhu J, Ding G, Liu Y, Wang B, Zhang W, Guo M, Geng Q, Cao Y (2015) Ionic liquid forms of clopyralid with increased efficacy against weeds and reduced leaching from soils. Chem Eng J 279:472-477. https://doi.org/10.1016/j.cej.2015.05.025

Publisher's Note Springer Nature remains neutral with regard to jurisdictional claims in published maps and institutional affiliations. 